\title{
Becoming Inclusive Teachers: Perspectives of Pre- service Teachers of Regional Institute of Education, Bhubaneswar on Inclusive Education
}

\author{
Manoj Kumar Swain' ${ }^{1}$, Laxmidhar Behera ${ }^{2 *}$, Amlesh Kumar ${ }^{3}$ and \\ Dhanya Krishnan ${ }^{4}$
}

${ }^{1}$ M.Ed. Student, ${ }^{2}$ Professor, ${ }^{3}$ Research Scholar, ${ }^{4}$ Assistant Professor

Regional Institute of Education, NCERT, Bhubaneswar, Odisha, India

*Corresponding author: behera17@yahoo.co.in

\begin{abstract}
Preparing educators for inclusive education setup and improving learning outcomes of children with special needs is a major concern across the globe. The present study explored student teachers' perspectives towards inclusive education. The study explored the experiences and preparation of secondary level pre-service teachers in theory and field-based activities for inclusive education. A descriptive survey method was used for this study. The research was limited to students studying at Regional Institute of Education, Bhubaneswar a constituent unit of NCERT, India. The sample consisted 125 final-semester student teachers $\left(8^{\text {th }}\right.$ semester student teachers from four-year integrated B.A.B.Ed., B.Sc.B.Ed. and $4^{\text {th }}$ semester student teachers from 2 year B.Ed. programmes). Attitude scale and self-developed questionnaire were used for this study. The result of the study revealed that, majority of the student teachers have optimistic attitudes toward inclusive education. Majority of the preservice teachers stated that theory and field engagement activities for inclusive education are helpful for preparing inclusive classroom teachers. But they also stated that these activities and conceptual papers are not enough for preparing inclusive classroom teachers. The study's findings have a wide range of consequences for teachers, teacher educators, and teacher education institutions as well as forthcoming research.
\end{abstract}

Keywords: Pre-service Teachers, Inclusive Education, Teacher Education Institutions

Inclusive education has become widely acknowledged as a philosophy for achieving educational fairness for all children, particularly those who have been excluded from conventional educational procedures

How to cite this article: Swain, M.K., Behera, L., Kumar, A. and Krishnan, D. (2021). Becoming Inclusive Teachers: Perspectives of Pre-service Teachers of Regional Institute of Education, Bhubaneswar on Inclusive Education. Learning Community, 12(01): 27-38. 
due to disability, ethnicity, gender, or other factors. Inclusive practices in educational institutions provide children with special needs (CWSNs), a fair chance to learn along with usually developed peers in the normal classroom, with adequate supports from the teachers (Downing \& Peckham-Hardin, 2007).The National Education Policy 2020 in India envisions inclusive and equitable education towards learning for all (MHRD,2020). Preparing student teachers in this connection will be catalyst for inclusive setup and its representation in future classroom practices. Understanding trainee teachers' attitudes toward inclusive education practices, as well as how pre-service teacher preparation programmes influence this formation, is critical (D'Alonzo, Giordano, \& Cross, 1996, Forlin, Loreman, Sharma, \& Earle, 2009, Kim, 2011). This attitude creation is a "learning process" that is influenced by a variety of contextual elements such as interactions with learners with varying needs, prior academic experience, and learners' self-efficacy (Ahsan, Sharma, \& Deppeler, 2012; Lambe \& Bones, 2006; Lassig, 2009). Attitudes are even context-dependent and responsive to factors within a socio-cultural environment (Bradshaw \& Mundia, 2005).

The significance of teacher's attitudes toward inclusive practices has been a contemporary subject of study in line with the possible influence of teacher's attitudes on the meaningful enactment of inclusive teaching-learning practices (Astha, Sushma, \& Smriti, 2012, Bhatnagar \& Ajay, 2014, Dias \& Cadime, 2016, Gaad \& Khan, 2007, Hsien, Brown, \& Bortoli, 2009, Leatherman \& Niemeyer, 2005, Niemeyer \& Proctor, 2002, Odongo \& Davidson, 2016, Seçer, 2010, Weiner, 2003).There is a definite movement toward inclusive education methods around the world, as well as in India, with widespread consensus on the core concepts first enshrined through the Salamanca Statement (UNESCO, 1994). Many agreements, declarations, and recommendations have been issued at the European and global levels since then, notably the "United Nations Convention on the Rights of Persons with Disabilities" (2006), which emphasizes the significance of establishing inclusive educational practices. In this context, student teachers are expected to begin their teaching careers as inclusive teachers equipped with the relevant techno pedagogical content knowledge, skills and abilities to meet the learning needs of every learner in their classes and deliver socially justifiable education for all. Teachers are in charge of serving the different needs of students. Teachers' favourable attitudes toward inclusive education practises must be reflected a necessity for its success in $21^{\text {st }}$ century classrooms, given their position in society as catalysts for educational reform.

\section{Rationale of the Study}

As classrooms become more diverse day by day, major changes have been necessary in terms of preparing teachers for more diverse learners. By focusing on preparing pre-service teachers for inclusive education is crucial for addressing learners' diversity and promoting teachers' keen sense of inclusive educational practices (Sharma, Forlin \& Loreman, 2008). In a study of teachers' views toward inclusive education, Parasuram (2006) discovered that teachers' attitudes were more favorable if they had worked with CWSNs. If children with special needs (CWSNs) are to be admitted in regular classes on an equal basis, then instructors' underlying prejudices and negative attitudes must be eliminated. Bansal (2016) had conducted research on "teachers' attitudes toward inclusive education and their professional 
commitment". The study reported that teachers in private schools had a more optimistic attitude toward inclusive education than teachers in public schools. However, other researchers have found that even after finishing professional development courses on inclusive educational methods, many teachers still have doubts about their competence to teach CWSNs, and some have doubts about whether they will be provided with appropriate teaching-learning resources and support (Avramidis, Bayliss, \& Burden, 2000; Kearney and Durand, 1992).

Murdaca, Oliva, and Costa (2018) claim that inclusive practices entail "a number of changes to curriculum, pedagogy, and assessment". While efficient coordination between teachers and students, schools, and other elements are important, it is mostly dependent on the teachers' learning experiences. Several factors influence teachers' attitudes toward inclusive practices, "including their gender (Alghazo \& Gaad, 2004), personal beliefs (Dupoux, Wolman, \& Estrada, 2005), the severity of the learners' disability (Langdon \& Vesper, 2000), as well as their training, learning experiences, and instructional skills (Haq \& Mundia, 2012)". According to "Kraska and Boyle (2014), pre-service teachers' views toward inclusive education is important since it can predict future attitudes regarding their teaching careers". The attitude and desire of teachers to allow CWSNs in their classes is one of the most important parts of the effectiveness of inclusive education practices. As a result, it is critical to analyze student teachers' views toward inclusive education. The study's purpose was to look at how student teachers perceived about inclusive education during their teaching-learning experiences at RIE Bhubaneswar. The study looked at the viewpoints of student teachers at various stages of their education to see if their year of education and past learning experiences with CWSNs influenced their views on becoming inclusive instructors.

\section{Research Questions}

1. What are the attitudes of pre-service teachers towards Inclusive Education?

2. How do pre-service teachers perceive their experiences and preparation in theory and field-based activities for inclusive education?

\section{Objectives of the Study}

1. To study the pre-service teachers' attitude towards inclusive education.

2. To study the experiences and preparation of secondary level pre-service teachers in theory and field based activities for inclusive education.

\section{Methodology}

The present study was a descriptive survey research. The study was delimited to students studying at RIE, Bhubaneswar. Approximately, 900 pre-service teachers are enrolled in various programmes at the institute. From there, 125 final-year students, i.e. $8^{\text {th }}$ semester trainee teachers of B.A.B.Ed., B.Sc.B.Ed., 
D Swain et al.

and $4^{\text {th }}$ semester trainee teachers of 2 year B.Ed., were randomly selected (from 246 final semester student teachers in total) as participants of the study. The final year students were taken as participants since they had completed maximum course components and requisite field engagement activities. Self-developed attitude scale and questionnaire as tools were used for collecting data. In this process, researcher had interacted with the participants and distributed the self-developed attitude scale and self-developed questionnaire to them and collected relevant responses. For exploring the attitude of student teachers towards becoming inclusive teachers, both qualitative and quantitative methods were used for the analysis of data.

\section{RESULTS}

\section{Pre-Service Teachers' Attitudes towards Inclusive Education}

Pre-service teachers are going to take the final charge in the near future and may face an Inclusive learning environment so, it becomes important to explore their viewpoint towards Inclusive Education. The following responses give an idea about their attitude towards inclusive education.

Table 1: Pre-Service Teachers Attitudes towards Inclusive Education $(\mathrm{N}=125)$

\begin{tabular}{|c|l|c|c|c|c|c|}
\hline SI. No. & Statements & SA (\%) & A (\%) & N (\%) & DA (\%) & SDA (\%) \\
\hline 1 & $\begin{array}{l}\text { The greatest way to meet the prerequisites of CWSNs } \\
\text { is to create separate classes for them. }\end{array}$ & 0 & 12 & 12 & 40 & 36 \\
\hline 2 & $\begin{array}{l}\text { There is a need to educate all students in a common } \\
\text { regular classroom }\end{array}$ & 32 & 56 & 0 & 8 & 4 \\
\hline 3 & $\begin{array}{l}\text { Special needed pupils will be comfortable in a regular } \\
\text { classroom. }\end{array}$ & 16 & 52 & 32 & 0 & 0 \\
\hline 4 & $\begin{array}{l}\text { Special needed pupils will require special guidance } \\
\text { and tutorial. }\end{array}$ & 16 & 52 & 20 & 12 & 0 \\
\hline 5 & $\begin{array}{l}\text { Special needed pupils will perform according to their } \\
\text { ability in a regular classroom. }\end{array}$ & 12 & 64 & 12 & 12 & 0 \\
\hline 6 & $\begin{array}{l}\text { The inclusion of CWSNs in a regular class can be } \\
\text { affected in the academic achievement of normal } \\
\text { students. }\end{array}$ & 0 & 12 & 16 & 60 & 12 \\
\hline 7 & $\begin{array}{l}\text { The Inclusion of CWSNs in a regular class will create } \\
\text { too much additional work }\end{array}$ & 16 & 32 & 4 & 48 & 0 \\
\hline 8 & $\begin{array}{l}\text { Inclusion of CWSNs is likely to have a negative } \\
\text { impact on a disabled student's emotional development. }\end{array}$ & 0 & 8 & 12 & 32 & 48 \\
\hline 9 & $\begin{array}{l}\text { Isolation in a special class is advantageous to a learner } \\
\text { with a disability's social and emotional development. }\end{array}$ & 8 & 4 & 8 & 24 & 56 \\
\hline 10 & $\begin{array}{l}\text { Inclusion appears to be a nice idea in theory, but it is } \\
\text { difficult to implement in practise. }\end{array}$ & 24 & 24 & 20 & 24 & 8 \\
\hline 11 & I feel comfortable while working with CWSNs. & 40 & 40 & 16 & 4 & 0 \\
\hline
\end{tabular}




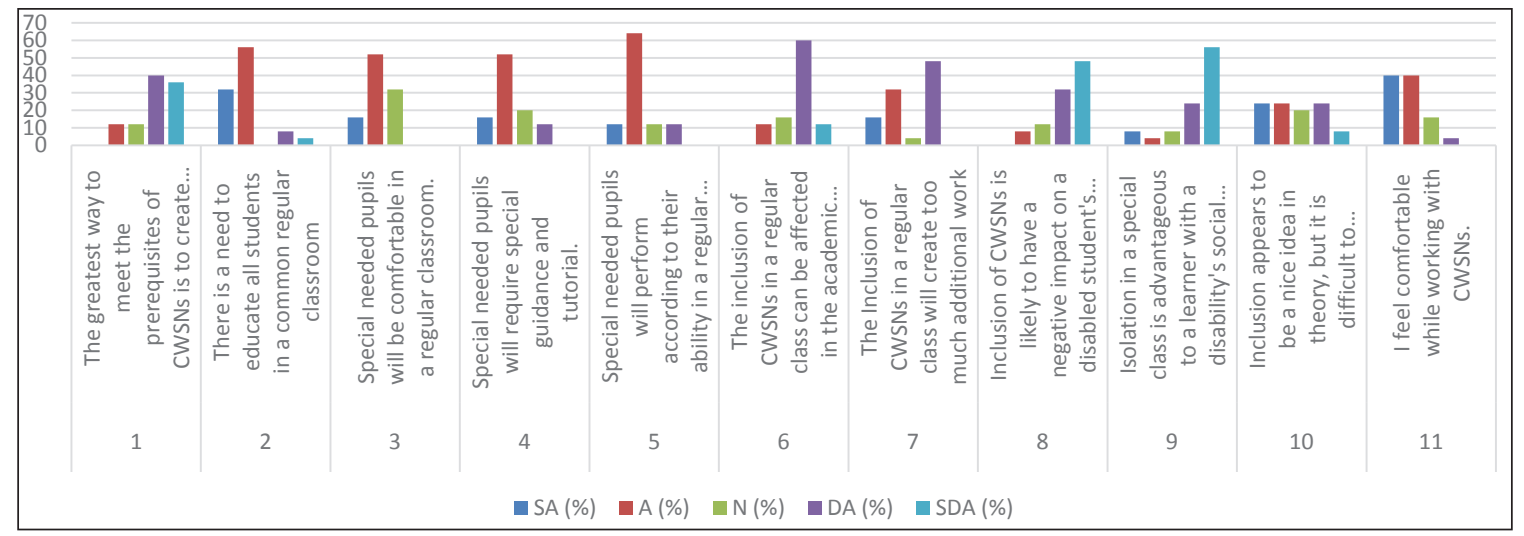

Fig. 1: Pre-Service Teachers attitudes towards Inclusive Education

The data reflected that student teachers had an optimistic attitude towards inclusive education. Student teachers were agreed on an inclusive classroom setup; they believe it will be more contextual than the regular classroom. They accept the fact that expertise is needed to teach special needed students in a regular classroom and they need special guidance and tutorial. They believe it will not affect the academic achievement of normal students. Pre-service teachers' responses to the learning environment of inclusive classrooms revealed that almost all of them strongly believe that inclusive classrooms will assist learners in understanding disparities among students and motivate them to accept these differences. In an inclusive classroom they can perform as per their ability and the learning environment will help them to develop their academic skills more rapidly, it will enhance their social and emotional aspect. Two third of them feels comfortable while working with students having a disability, they agreed that it will be difficult to address first-generation learners in a regular classroom. The classroom environment will be different and enjoyable when cultural diversity exists in the classroom. They believe that Inclusive education can be brought about in practice. When asked if a regular teacher can teach students with impairments, opinions vary; some believe that a special teacher can teach them better.

Table 2: Management of Inclusive Classrooms $(\mathrm{N}=125)$

\begin{tabular}{|c|l|c|c|c|c|c|}
\hline $\begin{array}{c}\text { Sl. } \\
\text { No. }\end{array}$ & Statements & SA (\%) & A (\%) & N (\%) & DA (\%) & SDA (\%) \\
\hline 1 & $\begin{array}{l}\text { It will be a challenge for a teacher to address first- } \\
\text { generation learners in a regular classroom. }\end{array}$ & 16 & 52 & 12 & 20 & 0 \\
\hline 2 & $\begin{array}{l}\text { It will be difficult to handle a classroom with cultural } \\
\text { diversity. }\end{array}$ & 0 & 12 & 12 & 36 & 40 \\
\hline 3 & $\begin{array}{l}\text { The extra attention needed by a pupil with a disability } \\
\text { will be to the disadvantage of the other pupils. }\end{array}$ & 4 & 12 & 12 & 36 & 36 \\
\hline 4 & $\begin{array}{l}\text { It needs the expertise to teach special needed students } \\
\text { in a regular classroom. }\end{array}$ & 52 & 28 & 4 & 16 & 0 \\
\hline
\end{tabular}




\begin{tabular}{|c|l|c|c|c|c|c|}
\hline 5 & $\begin{array}{l}\text { It's not difficult to keep order in an normal classroom } \\
\text { that has CWSNs than in one that does not have a } \\
\text { CWSNs. }\end{array}$ & 8 & 52 & 12 & 28 & 0 \\
\hline 6 & $\begin{array}{l}\text { An Inclusive set up classroom will be more contextual } \\
\text { than the regular classroom. }\end{array}$ & 36 & 36 & 20 & 8 & 0 \\
\hline 7 & $\begin{array}{l}\text { The Inclusion of CWSNs will require significant } \\
\text { changes in regular classroom practices. }\end{array}$ & 68 & 24 & 8 & 0 & 0 \\
\hline 8 & $\begin{array}{l}\text { A special education teacher is better at teaching } \\
\text { CWSN than a standard classroom instructor. }\end{array}$ & 8 & 48 & 20 & 16 & 8 \\
\hline 9 & $\begin{array}{l}\text { CWSNs' academic advancement will be aided by the } \\
\text { challenge of being in a regular classroom. }\end{array}$ & 12 & 72 & 16 & 0 & 0 \\
\hline 10 & $\begin{array}{l}\text { A Multilingual approach will be appropriate to deal } \\
\text { with different language students in a classroom. }\end{array}$ & 60 & 28 & 8 & 4 & 0 \\
\hline
\end{tabular}



Fig. 2: Management of Inclusive Classrooms

The data showed that pre-service teachers are aware of managing inclusive classrooms. They believe that management will have to play a crucial role in designing different classroom activities looking at the need of the pupils. There exists confusion about whether the pupils will be able to monopolize the regular teacher's time. Inclusion will lead to changes in the classroom practices which usually happens in a regular classroom. Pre-service teachers believe isolation of pupils having difficulty will not benefit their social and emotional development. They believe extra attention needed for children with disability. 
Becoming Inclusive Teachers: Perspectives of Pre-service Teachers of Regional...

Table 3: Outcome of Inclusive Education

\begin{tabular}{|c|l|c|c|c|c|c|}
\hline SI. No. & Statements & SA (\%) & A (\%) & N(\%) & DA (\%) & SDA (\%) \\
\hline 1 & $\begin{array}{l}\text { The Inclusion of male, female and 3r gender } \\
\text { students will create a gender sensitisation in a regular } \\
\text { classroom. }\end{array}$ & 40 & 32 & 12 & 12 & 4 \\
\hline 2 & $\begin{array}{l}\text { Inclusion allows students to interact in mixed groups, } \\
\text { which promotes awareness and accepting of diversity. }\end{array}$ & 60 & 32 & 4 & 4 & 0 \\
\hline 3 & $\begin{array}{l}\text { Regular classroom help to the developed social and } \\
\text { emotional aspects of CWSN. }\end{array}$ & 48 & 44 & 8 & 0 & 0 \\
\hline 4 & $\begin{array}{l}\text { In a conventional classroom, the CWSN will most } \\
\text { likely develop academic skills faster than in a special } \\
\text { school. }\end{array}$ & 32 & 40 & 24 & 4 & 0 \\
\hline 5 & $\begin{array}{l}\text { The inclusion of CWSNs in a regular classroom can } \\
\text { be beneficial for pupils without disabilities. }\end{array}$ & 36 & 44 & 20 & 0 & 0 \\
\hline 6 & $\begin{array}{l}\text { The Inclusion of special needed pupils in the regular } \\
\text { classrooms will help to be aware of equal rights. }\end{array}$ & 52 & 36 & 8 & 4 & 0 \\
\hline 7 & $\begin{array}{l}\text { The Inclusion of CWSN in a regular class will } \\
\text { improve his/her social independence. }\end{array}$ & 72 & 24 & 0 & 4 & 0 \\
\hline
\end{tabular}

\begin{tabular}{|c|c|c|c|c|c|c|c|}
\hline \multirow[t]{4}{*}{$\begin{array}{r}80 \\
70 \\
60 \\
50 \\
40 \\
30 \\
20 \\
10 \\
0\end{array}$} & 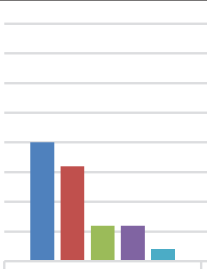 & In & $\square$ & = & & n & \\
\hline & $\begin{array}{l}\text { The Inclusion of } \\
\text { male, female } \\
\text { and 3rd gender } \\
\text { students will } \\
\text { create a gender } \\
\text { sensitisation in } \\
\text { a regular } \\
\text { classroom. }\end{array}$ & $\begin{array}{l}\text { Inclusion allows } \\
\text { students to } \\
\text { interact in } \\
\text { mixed } \\
\text { groups, which } \\
\text { promotes } \\
\text { awareness and } \\
\text { accepting of } \\
\text { diversity. }\end{array}$ & $\begin{array}{l}\text { Regular } \\
\text { classrooms help } \\
\text { to develop the } \\
\text { social and } \\
\text { emotional } \\
\text { aspects of } \\
\text { CWSN. }\end{array}$ & $\begin{array}{l}\text { In a } \\
\text { conventional } \\
\text { classroom, the } \\
\text { CWSN will most } \\
\text { likely develop } \\
\text { academic skills } \\
\text { faster than in a } \\
\text { special school. }\end{array}$ & $\begin{array}{l}\text { The inclusion of } \\
\text { CWSNs in a } \\
\text { regular } \\
\text { classroom can } \\
\text { be beneficial for } \\
\text { pupils without } \\
\text { disabilities. }\end{array}$ & $\begin{array}{l}\text { The Inclusion of } \\
\text { special needed } \\
\text { pupils in the } \\
\text { regular } \\
\text { classrooms will } \\
\text { help to be } \\
\text { aware of equal } \\
\text { rights. }\end{array}$ & $\begin{array}{l}\text { The Inclusion of } \\
\text { CWSN in a } \\
\text { regular class } \\
\text { will improve } \\
\text { his/her social } \\
\text { independence. }\end{array}$ \\
\hline & 1 & 2 & 3 & 4 & 5 & 6 & 7 \\
\hline & & & $\%) \quad A(\%)$ & $\mathrm{N}(\%)$ & $\%) \quad \operatorname{SDA}(\%)$ & & \\
\hline
\end{tabular}

Fig. 3: Outcome of Inclusive Education

The data shows that pre-service teachers were aware of the outcome of inclusive classrooms in terms of creating equity in classrooms and achieving excellence in education. Pre-service teacher's outlook towards the output of Inclusive Education as shown in the graph above gives positive aspects about their 
D Swain et al.

thought on Inclusive Education. The Inclusion of male, female and third gender will create a sensitisation in a regular classroom. The Inclusion of CWSNs in a regular classroom would benefit pupils without disabilities. Inclusion, according to three-quarters of them, will have a good impact on a differently abled student's emotional development, allowing them to strengthen their social independence. They believe that, children with special needs will certainly make a reasonable effort to complete their homework.

\section{Pre-service Teachers Perception and Experiences in theory and field-based activities for Inclusive Education}

Pre-service teachers have developed certain perceptions and understandings about inclusive education as a result of their involvement in various teaching-learning processes such as theory classes, field visits, and a variety of activities such as multicultural placement programmes, internships, community work, and so on. The following can be referenced about their perceptions and experiences with inclusive education based on the responses received through the open-ended questions. Student teachers have a positive attitude and are trained to be in inclusive education. They want no discrimination and care for students in an inclusive setting, and they believe the government should/must make some adjustments to the inclusive education policy and focus more on implementation. Pre-service teachers had a strong opinion on inclusive teaching-learning practices. They believe Multicultural/ internship/ community work has added to their knowledge base on inclusivity, as while being involved in these activities they had a chance to observe a wide variety of learners and know their challenges and difficulties being faced by them, which definitely enriched their experiences and also brought about change in their perception for inclusive education setup. Participating in numerous learning-teaching activities during their teacher education programme brought them closer to the students, allowing them to expand their experiences, which will aid them when functioning as a tutor or mentor. To prepare secondary level student teachers for inclusive education settings, the teacher education program's curriculum is critical. It prepares teachers' professional standards, which are critical for managing an inclusive educational setting. This will be reflected in their attitude through more field work and putting theoretical and policy into practise.

\section{Major Findings of the Study}

The study found that most of the participants have positive attitude towards inclusive education.

Participants were also sensitive towards teaching-learning practices in inclusive classrooms.

Majority of secondary pre-service teachers believe that theory and field engagement activities for inclusive education are more beneficial in developing inclusive classroom teachers. However, they also note that these activities and conceptual papers are insufficient in training mentors for inclusive classrooms.

Majority of the participants stated that they gained a lot of learning experiences about the concept of inclusive education during their training programme, they discovered a lot of teaching-learning 
resources that are useful for teaching inclusive classrooms, they explored different instructional strategies that are useful for inclusive classrooms, and also they gained necessary skills regarding managing inclusive classrooms.

The study also found that all the field engagement activities in the B.Ed., BA. B.Ed. and B.Sc. B.Ed. curricula are connected to inclusive education and are assisting student teachers in preparing themselves for inclusive classrooms.

\section{DISCUSSION}

Inclusive education is a key area, which is included in the educational policies of governments across the globe, and in this $21^{\text {st }}$ century, there is a wide range of collective consensus among different stakeholders about inclusion as a desirable goal. The results of the research on student teachers' attitudes toward inclusive education demonstrate that the majority of sampled pre-service teachers have a positive attitude towards inclusive teaching-learning practices. However, many are unaware of the notion of inclusive education and believe that a special school is the greatest option for the education of disabled children. Many of the studies showed the positive attitudes toward inclusive education (Taylor, \& Ringlaben, 2012; Goddard \& Evans, 2018; Galicia \& Brojcin \& Glumbric, 2014 and Das \& Bhatnagar, 2014).

Findings of the study pertaining to experience and preparation of student teachers in theory and field engagement programs for inclusive education indicates that all the pre-service teachers are aware about significance of inclusive education. The majority of the student teachers stated that the theory of teacher education curriculum is more helpful for understanding the different concepts related to inclusive education like meaning, nature, the importance of inclusive education, individual difference, different types of children's needs, abilities, different instructional strategies, how to prepare their self. Also, majority of the pre-service teachers accept that theory paper of teacher education curriculum is more helpful for preparing their self for the inclusive classroom. On the other side, pre-service teachers opined that in the field engagement program of pre-service teacher education, there are many activities which are more helpful for developing different skills of the student teachers for the inclusive classroom. But few pre-service teachers gave their opinion that theory and field-based activities are not sufficient for preparing inclusive classroom teachers.

\section{Educational Implications}

The following are some of the implications of the findings of this study for educational planners, policy makers, administrators, teacher educators, and students:

1. Attitude is the most important mental process of people. Because every successful work depends on the people's attitude. Attitude helps to make interest, attention to any work. The study's findings demonstrated that pre-service teachers had favourable opinions about inclusive educational approaches. As a result, pre-service teachers' positive attitudes are more beneficial for practising or teaching in inclusive classrooms. 
2. Pre-service teacher's opinions about their learning experiences and gaining skills for inclusive educational practices are helpful for them to become sensitive future teachers. The present study has found variety of teaching-learning tools, instructional methodologies, and techniques for self-preparation for an inclusive classroom.

3. This study is significant for educational planners, policy-makers and curriculum developers for designing better learning experiences for student teachers towards inclusive education.

4. The field engagement activities need to have exposure to different types of schools so as to develop field based knowledge related to inclusive education.

\section{CONCLUSION}

Addressing needs of all learners in the classroom is one of the most difficult tasks for teachers in the twenty-first century. Teacher education institutions have a critical role in educating pre-service teachers for inclusive teaching and learning practises in this context. The primary purpose of teacher education programmes is to generate competent, qualified, and newly knowledgeable teachers capable of performing their jobs efficiently in every situation. In the twenty-first century, education systems should focus on preparing inclusive education teachers. In order to reach this goal and incorporate these new trends, effective teacher development programmes are essential. This study looked into and analysed the student teachers' viewpoints on inclusive education as well as their personal experiences during the field engagement programme. The study's conclusions reflected that student teachers had favourable attitude towards inclusive education because all the final year trainee student teachers learned about inclusive education and practices during their course. It was also noted that while many topics linked to inclusive practises are constantly mentioned in courses, but still more learning experiences on inclusive teaching-learning methods are required for student teachers in order to achieve desired outcomes. This study emphasises the relevance of teacher education institutions in educating pre-service teachers to engage more fully with inclusive education practices.

\section{REFERENCES}

1. Ahsan, M.T., Sharma, U. and Deppeler, J.M. 2012. Exploring pre-service teachers' perceived teaching efficacy, attitudes and concerns about inclusive education in Bangladesh. International Journal of Whole Schooling, 8(2): 1-20.

2. Alghazo, E. and Gaad, E. 2004. General education teachers in the United Arab Emirates and their acceptance of the inclusion of students with disabilities. British Journal of Special Education, 31: 94-99.

3. Astha, S., Sushma, S. and Smriti, B. 2012. In-service primary teachers' attitude towards inclusion: Survey results from district Kurukshetra (Haryana). GYANODAYA: The Journal of Progressive Education, 5(2): 25-30.

4. Avramidis, E., Bayliss, P.D. and Burden, R. 2000. A Survey into Mainstream Teachers' Attitudes Towards the Inclusion of Children with Special Educational Needs in the Ordinary School in one Local Education Authority, Educational Psychology: An International Journal of Experimental Educational Psychology, 20(2): 191-211. 
Becoming Inclusive Teachers: Perspectives of Pre-service Teachers of Regional...

5. Bansal, S. 2016. Attitude of Teachers towards Inclusive Education in Relation to their Professional Commitment, Indian Journal of Educational Studies: An Interdisciplinary Journal, 3(1): 96-108.

6. Bhatnagar, N. and Ajay, D. 2014. Attitudes of secondary regular school teachers toward inclusive education in New Delhi, India: A qualitative study. Exceptionality Education International, 24(2): 17-30.

7. Bradshaw, L. and Mundia, L. 2005. Understanding pre-service teachers' construct of disability: A metacognitive process. Disability \& Society, 20(5): 563-574.

8. D’Alonzo, B.J., Giordano, G. and Cross, T.L. 1996. Improving teachers' attitudes through teacher education toward the inclusion of students with disabilities into their classrooms. Teacher Education, 31(4): 304-312.

9. Dias, P. and Cadime, I. 2016. Effects of personal and professional factors on teachers' attitudes towards inclusion in preschool. European Journal of Special Needs Education, 31: 111-123.

10. Downing, J.E. and Peckham-Hardin, K.D. 2007. Inclusive Education: What Makes It a Good Education for Students With Moderate to Severe Disabilities? Research and Practice for Persons with Severe Disabilities, 32(1): 16-30.

11. Dupoux, E., Wolman, C. and Estrada, E. 2005. Teachers' attitudes toward integration of students with disabilities in Haïti and the United States. International Journal of Disability, Development and Education, 52: 43-58.

12. Forlin, C., Loreman, T., Sharma, U. and Earle, C. 2009. Demographic differences in changing pre-service teachers' attitudes sentiments and concerns about inclusive education. International Journal of Inclusive Education, 13(2): 195-209.

13. Gaad, E. and Khan, L. 2007. Primary mainstream teachers' attitudes towards inclusion of students with special educational needs in the private sector: A perspective from Dubai. International Journal of Special Education, 22: 95-109.

14. Galović, D., Brojčin, B. and Glumbić, N. 2014. The attitudes of teachers towards inclusive education in Vojvodina. International Journal of Inclusive Education, 18(12): 1262-1282.

15. Goddard, C. and Evans, D. 2018. Primary Pre-Service Teachers' Attitudes Towards Inclusion Across the Training Years. Australian Journal of Teacher Education, 43(6).

16. MHRD. 2020. National Education Policy 2020, New Delhi, Government of India. https://www.education.gov.in/ sites/upload_files/mhrd/files/NEP_Final_English_0.pdf

17. Haq, F. and Mundia, L. 2012. Comparison of Brunei pre-service student teachers' attitudes to inclusive education and specific disabilities: Implications for teacher education. The Journal of Educational Research, 105: 366-374.

18. Hsien, M., Brown, P. and Bortoli, A. 2009. Teacher qualifications and attitudes toward inclusion. Australasian Journal of Special Education, 33: 26-41.

19. Kearney, C.A. and Durand, V.M. 1992. How Prepared are Our Teachers for Mainstreamed Classroom Settings? A Survey of Postsecondary Schools of Education in New York State. Exceptional Children, 59(1): 6-11.

20. Kim, J. 2011. Influence of teacher preparation programmes on pre-service teachers' attitudes toward inclusion. International Journal of Inclusive Education, 15(3): 355-377.

21. Kraska, J. and Boyle, C. 2014. Attitudes of preschool and primary school pre-service teachers towards inclusive education. Asia- Pacific Journal of Teacher Education, 42: 228-246. 
22. Lambe, J. and Bones, R. 2006. Student teachers' perceptions about inclusive classroom teaching in Northern Ireland prior to teaching practice experience. European Journal of Special Needs Education, 21(2): 167-186.

23. Lassig, C. 2009. Teachers' attitudes towards the gifted: The importance of professional development and school culture. The Australasian Journal of Gifted Education, 18(2): 32-42.

24. Leatherman, J. and Niemeyer, J. 2005. Teachers' attitudes toward inclusion: Factors influencing classroom practice. Journal of Early Childhood Teacher Education, 26: 23-36.

25. Loreman, T. and Earle, C. 2007. The development of attitudes, sentiments and concerns about inclusive education in a content-infused Canadian teacher preparation program. Exceptionality Education Canada, 17(1/2): 85-106.

26. Murdaca, A., Oliva, P. and Costa, S. 2018. Evaluating the perception of disability and the inclusive education of teachers: The Italian validation of the SACIE-R (Sentiments, Attitudes, and Concerns about Inclusive EducationRevised Scale). European Journal of Special Needs Education, 33: 148-156.

27. Niemeyer, J. and Proctor, R. 2002. The influence of experience on student teachers' beliefs about inclusion. Journal of Early Childhood Teacher Education, 23: 49-57.

28. Odongo, G. and Davidson, R. 2016. Examining the attitudes and concerns of the Kenyan teachers toward the inclusion of children with disabilities in the general education classroom: A mixed methods study. International Journal of Special Education, 31(2): 1-30.

29. Parasuram, K. 2006. Variables that affect teachers' attitudes towards disability and inclusive education in Mumbai, India, Disability \& Society, 21(3): 231-242.

30. Seçer, Z. 2010. An analysis of the effects of in-service teacher training on Turkish preschool teachers' attitudes towards inclusion. International Journal of Early Years Education, 18: 43-53.

31. Sharma, U., Forlin, C. and Loreman, T. 2008. Impact of training on pre-service teachers' attitudes and concerns about inclusive education and sentiments about persons with disabilities. Disability \& Society, 23(7): 773-785.

32. Taylor, R.W. and P. Ringlaben, R. 2012. Impacting Pre-service Teachers' Attitudes toward Inclusion. Higher Education Studies, 2(3): 16-23.

33. UNESCO. 1994. The Salamanca Statement and Framework for Action on Special Needs Education. Paris: UNESCO.

34. Weiner, M. 2003. Effective inclusion: Professional development in the context of the classroom. Teaching Exceptional Children, 35(6): 12-18. 